\title{
Peningkatan Aktivitas dan Hasil Belajar IPS melalui Penerapan Metode STAD pada Peserta Didik Kelas VIII
}

\author{
Harnieti \\ Dinas Pendidikan Kabupaten Lima Puluh Kota \\ $\supseteqq$ e-mail: harnieti_1973@yahoo.com
}

\begin{abstract}
Abstrak
Artikel ini bertujuan untuk mengungkapkan tentang peningkatan aktivitas dan hasil belajar pseerta didik dengan menerapkan metode STAD pada kelas VIII.8 SMPN 1 Kecamatan Luak Semester 2 Tahun Pelajaran 2014/2015. Penelitin ini merupakan penelitian tindakan kelas yang dilaksanakan sebanyak 2 siklus, dan masing-masing siklus dilaksanakan selama 3 kali pertemuan. Penelitian ini bertujuan untuk memberikan tambahan informasi dan pemikiran tentang salah satu dari sekian banyak metode pembelajaran yang dapat diterapkan untuk meningkatkan kompetensi peserta didik. Adapun teknik pengumpulan data dilakukan dengan observasi langsung dan didampingi oleh teman sejawat sebagai observer dengan menggunakan lembar observasi. Kemudian hasil pengamatan akan dianalisis dengan melihat peningkatannya dalam setiap siklus. Keberhasilan penerapan model, pemilihan media, strategi, maupun pendekatan pembelajaran tentunya dipengaruhi oleh berbagai faktor. Namun penelitian ini setidaknya memberikan gambaran bagaimana seorang guru berusaha untuk meningkatkan aktivitas dan hasil belajar peserta didik melalui proses pembelajaran yang berkualitas dan menyenangkan.
\end{abstract}

Kata Kunci: Peningkatan Aktivitas, Hasil Belajar, Metode STAD

Copyright (C) 2017 IICET (Indonesia) - All Rights Reserved

Indonesian Institute for Counseling, Education and Therapy (IICET)

\section{PENDAHULUAN}

Pasal 3 Undang-undang Sistem Pendidikan Nasional Nomor 20 Tahun 2003 dijelaskan bahwa :

"Pendidikan nasional berfungsi mengembangkan kemampuan dan membentuk watak serta peradaban bangsa yang bermanfaat dalam rangka mencerdaskan kehidupan bangsa, bertujuan untuk berkembangnya potensi peserta didik agar menjadi manusia yang beriman, dan bertakwa kepada Tuhan Yang Maha Esa, berakhlak mulia, berilmu, cakap,kreatif, mandiri dan menjadi warga negara yang demokrasi serta bertanggungjawab".

Akhir-akhir ini masyarakat sering memperbincangkan mengenai mutu pendidikan yang terus menurun dari waktu ke waktu. Indikasinya adalah rendahnya hasil belajar peserta didik, tingginya persentase kegagalan peserta didik dalam menempuh ujian akhir sekolah, rendahnya pengetahuan dan keterampilan lulusan sehingga tidak siap masuk ke dunia kerja dan lain sebagainya. Beberapa pakar pendidikan menuding rendahnya mutu pendidikan disebabkan guru kurang professional dalam mengelola pembelajaran (Suhardan, D. 2007). Hal ini terlihat dari proses belajar mengajar masih didominasi oleh guru. Guru mengajar lebih banyak berceramah, menonton, kaku, banyak materi hafalan, sehingga peserta didik tidak aktif dalam kegiatan belajar.

Guru sebagai salah satu komponen pendidikan memegang peranan penting dalam upaya meningkatkan mutu pendidikan (Syamsuri, I. 2010; Purwanti, S. 2013), karena disamping melakukan kegiatan pengelolaan kelas juga melaksanakan kegiatan belajar mengajar yang meliputi proses mengatur, mengorganisasikan 
lingkungan yang ada di sekitar peserta didik. Semua komponen pengajaran yang meliputi tujuan, bahan pelajaran, kegiatan belajar mengajar, metode, alat dan sumber serta evaluasi diperankan secara optimal agar proses pembelajaran berlangsung dengan baik.

Proses pembelajaran yang di dalamnya terdapat interaksi anatara guru dan peserta didik dalam menjalankannya dibutuhkan sebuah strategi yang baik. Strategi bertujuan untuk memamksimalkan kemampuan dan hasil belajar yang diperoleh setelah melakukan pembelajaran. Guru semestinya memiliki kemampuan dalam menentukan dan merancang strategi pembelajaran yang tepat dan sesuai dengan materi pembelajaran agar dapat mendorong motivasi dan aktifitas peserta didik dalam pembelajaran, yang pada akhirnya diharapkan mampu meningkatkan hasil belajarnya. Menurut Amri (2013; Gustus, T. 2012), strategi adalah perencanaan dan tindakan yang tepat dan cermat mengenai kegiatan pembelajaran agar Kompetensi Dasar dapat tercapai.

Hal ini senada dengan yang disampaikan Roestiyah (2012)," Didalam proses belajar mengajar, guru selayaknya dapat menggunakan strategi, agar peserta didik dapat belajar secara efektif dan efisien, mengena pada tujuan yang diharapkan. Mata Pelajaran IPS merupakan salah satu mata pelajaran yang ada pada jenjang pendidikan Sekolah Menengah Pertama (SMP) dan tidak sedikit peserta didik yang merasa bosan dan kesulitan dalam mempelajari IPS. Apabila hal ini dibiarkan saja tanpa ada solusi dikawatirkan mutu pendidikan, khususnya mata pelajaran IPS akan menurun dan IPS tidak lagi diminati oleh peserta didik.

Berdasarkan permasalahan di atas tulisan ini akan membahas tentang Peningkatan Aktivitas dan Hasil Belajar IPS Melalui Penerapan Metode STAD Pada Peserta Didik Kelas VIII.

\section{METODOLOGI}

Penelitian Tindakan Kelas ini dilaksanakan di SMPN1 Kecamatan Luak pada Kelas VIII.8, Semester 2 TP. 2014/2015, yaitu pada bulan bulan April sampai dengan Juni 2015. Pendekatan yang digunakan adalah Kooperatif Learning (Johnson, D. W., \& Johnson, R. T. 1994; Sharan, S. E. 1994), dengan mengambil model STAD (Student Teams-Achievement Divisions). Penelitian ini bermaksud melihat peningkatan aktivitas dan hasil belajar IPS dengan menggunakan metode STAD.

Adapun teknik pengumpulan data dilakukan dengan observasi langsung dan didampingi oleh teman sejawat sebagai observer dengan menggunakan lembar observasi. Kemudian hasil pengamatan akan dianalisis dengan melihat peningkatannya dalam setiap siklus, dengan menggunakan kuisioner,catatan lapangan, lembar observasi dan hasil tes.

Teknik analisis data adalah dengan menngunakan rumus sebagai berikut : Aktivitas

$=$ Peserta Didik yang aktif $\times 100 \%$

Jumlah siswa seluruhnya

Hasil Belajar

$=\underline{\text { Peserta Didik yang Tuntas }} \times 100 \%$

Jumlah Peserta Didik Seluruhnya

Indikator Keberhasilan yang ditetapkan adalah aktivitas dan hasil belajar. Aktivitas meliputi (1) mendengarkan penjelasan guru (85\%), (2) mengerjakan tugas kelompok (80\%), (3) bertanya (50\%), (4) menjawab pertanyaan $(50 \%)$, (5) berpendapat (50\%), dan (6) membuat kesimpulan (85\%). Tercapainya ketuntasan klasikal $75 \%$ berdasarkan KKM yang teah ditetapka yaitu 75 dan Nilai rata-rata 75.

\section{HASIL DAN PEMBAHASAN \\ Hasil Penelitian}

Hasil penelitian diperoleh melalui data yang dikumpulkan berdasarkan instrumen pengamatan selama penelitian berlangsung, dan juga berdasarkan pengamatan terhadap proses kegiatan belajar mengajar di kelas peneliti. Dan juga berdasarkan tingkah laku guru peneliti dan siswa yang dijadikan sasaran peneliti. Hasil penelitian tersebut disimpulkan secara kualitatif dan kuantitif. Hasil kualitatif disimpulkan berdasarkan 
pengamatan terhadap tingkah laku guru peneliti dan siswa. Sedangkan hasil kuantitatif disimpulkan berdasarkan hasil kemampuan belajar siswa. Adapun hasilnya adalah sebagai berikut:

\section{SIKLUS I}

Setelah diadakan tindakan pada siklus I, terdapat beberapa keuntungan dan kesulitan, baik pada guru peneliti maupun siswa selama pelaksanaan pembelajaran.

Keuntungan bagi guru: (1) guru semakin paham dengan metode pembelajaran IPS sesuai dengan tuntutan kurikulum, (2) meningkatkan kerjasama guru mata pelajaran IPS di sekolah tempat penelitian diadakan, (3) guru termotivasi untuk mempersiapkan segala perangkat pembelajaran, (4) termotivasi untuk mempersiapkan media/alat pembelajaran, (5) guru lebih percaya diri, (6) guru mengetahui kekurangan dan kelemahannya dalam melaksanakan pembelajaran, dan (7) Guru berusaha menggunakan waktu pembelajaran dengan efektif dan efisien

Keuntungan bagi peserta didik diantaranya: (1) peserta didik termotivasi dalam belajar IPS, (2) peserta didik yang biasanya pemalu dan kemampuannya kurang berusaha mengimbangi kawannya yang pandai, (3) peserta didik memiliki tanggung jawab dan percaya diri, (4) kerjasama dalam kelompok sangat jelas, (5) peserta didik lebih mudah dalam memahami konsep-konsep dalam IPS, (6) timbul keberanian peserta didik dalam mengemukakan pendapat, (7) peserta didik lebih menghargai pendapat orang lain, dan (9) suasana belajar mulai tampak aktif.

Kesulitan yang dihadapi oleh guru diantaranya: (1) guru belum terbiasa sebagai fasilitator dalam pembelajaran, (2) repotnya mempersiapkan materi / bahan ajar sesuai dengan materi pembelajaran, (3) repotnya mempersiapkan media / alat yang dibutuhkan sesuai dengan bahan ajar, (4) kurangnya waktu pembelajaran, dan (5) kewalahan dalam mengelola kelas, karena sebagian siswa masih ada yang tidak serius.

Kesulitan yang dihadapi oleh peserta didik antara lain: (1) belum terampil dalam menggunakan alat / media yang digunakan sesuai bahan ajar, (2) masih ada peserta didik yang sulit dalam mengambil kesimpulan karena kurangnya buku referensi, (3) sebagian peserta didik kesulitan dalam menyampaikan informasi kepada teman-temannya dalam kelompok, dan (4) sebagian peserta didik belum berani tampil untuk mempresentasekan hasil kerja kelompok.

\section{SIKLUS II}

Pada siklus II guru peneliti telah melakukan perbaikan dan penyempurnaan terhadap terhadap langkahlangkah pembelajaran. Pada siklus II terdapat perobahan sikap guru dan peserta didik yang cukup baik terhadap pembelajaran IPS. Perubahan sikap tersebut adalah sebagai berikut:

Dari sisi guru antara lain: (1) guru selalu berupaya mempersiapkan perangkat pembelajaaran dengan baik, (2) disiplin guru meningkat dalam pelaksanaan pembelajaran di kelas, (3) guru lebih peka terhadap jam mengajarnya, sehingga tidak pernah terlambat masuk kelas, (3) guru semakin mengerti dengan metode pembelajaran IPS yang sesuai dengan tuntutan kurikulum,bahkan mampu mengimbaskan pada teman sejawatnya, dan (4) guru lebih sering berdiskusi terutama dengan teman sejawat, guna mencari soslusi dari setiap permasalahan yang ditemukan dalam proses pembelajaran.

Selanjutnya dilihat dari sisi peserta didik meliputi: (1) motivasi belajar peserta didik meningkat,karena metode yang digunakan guru lebih bervariasi (tidak hanya ceramah), (2) peserta didik merasa lebih dihargai karena setiap mereka punya kesempatan untuk mengemukakan pendapat, (3) peserta didik dapat saling berbagi informasi waktu kerja kelompok, (4) peserta didik yang kemampuan daya serapnya rendah lebih terbantu dalam kerja kelompok, (5) aktifitas peserta didik dalam belajar semakin meningkat, (6) peserta didik mulai percaya diri dalam menyampaikan pendapatnya, dan (7) tanggung jawab peserta didik meningkat, karena dalam pembelajaran mereka dituntut untuk tampil menyampaikan hasil yang diperoleh setelah diskusi dan untuk meningkatkan capaian skor atau nilai kelompoknya.

\section{Pembahasan}

Dari hasil penelitian ini ada beberapa hal yang menarik bagi peneliti yang perlu untuk dibahas dan dapat digunakan untuk masa mendatang. Dengan metode kooperatif learning model STAD dapat meningkatkan: (1) motivasi dan kesiapan belajar peserta didik, (2) aktifitas peserta didik dalam belajar, (3) pemahaman konsepkonsep dan materi dalam pelajaran IPS, (4) kinerja guru dalam proses belajar mengajar, (5) keberanianpeserta 
didik dalam bertanya dan menjawab pertanyaan serta mengemukakan pendapat, (6) rasa tanggung jawab peserta didik mulai meningkat, dan (6) hasil belajar peserta didik.

Selama proses perbaikan pembelajaran berlangsung guru tidak merasakan kesulitan karena peserta didik lebih aktif. Jawaban peserta didik dalam diskusi lebih terarah pada sasaran dan pencapaian tujuan pembelajaran, sehingga tindakan yang menyimpang dalam pembelajaran semakin berkurang. Hal ini tentu saja memberikan kepuasan bagi guru. Untuk mencapai itu semua guru harus banyak berkorban, baik waktu, tenaga, pikiran, demi mencapai hasil yang maksimal.

\section{Deskripsi Kondisi Awal}

Sebelum dilaksanakan Penelitian Tindakan Kelas (PTK) ini maka terlebih dahulu peneliti melakukan observasi terhadap kondisi awal pada aktivitas dan hasil belajar peserta didik kelas VIII.8 SMPN 1 Kecamatal Luak. Data yang diperoleh dapat digambarkan baik secara kuantitatif maupun kualitatif sebagai diantaranya: (1) mendengarkan penjelasan guru $(69,57 \%)$, (2) mengerjakan tugas kelompok $(60,87 \%)$, (3) bertanya $(17,39 \%)$, (4) menjawab pertanyaan $(30,44 \%)$, (5) berpendapat $(13,04 \%)$, dan (6) membuat kesimpulan $(69,57 \%)$. Sedangkan nilai pre tes dengan rata-rata 63,13 .

\section{Hasil Pengamatan pada Siklus 1}

Sedangkan berdasarkan pengamatan pada siklus 1 terdapat peningkatan meliputi: (1) mendengarkan penjelasan guru $(76,81 \%)$, (2) mengerjakan tugas kelompok $(72,46 \%)$, (3) bertanya $(28,99 \%)$, (4) menjawab pertanyaan $(42,03 \%),(5)$ berpendapat $(30,43 \%)$, dan (6) membuat kesimpulan $(79,71 \%)$.

Berdasarkan datal di atas dapat diambil kesimpulan bahwa terdapat peningkatan aktivitas peserta didik pada siklus 1 dibandingkan dengan kondisi awal, namun aktivitas bertanya, menjawab pertanyaan dan berpendapat masih rendah yaitu dengan rata-rata $28,99 \%, 42,03 \%$ dan $30,43 \%$.

Hasil Belajar berdasarkan tes yang diadakan pada siklus 1 adalah dengan rata-rata 76,83, dimana sudah mampu mencapai target yang ditetapkan. Artinya terdapat peningkatan Hasil Belajar peserta didik pada siklus 1 dibandingkan dengan kondisi awal sebesar 17,39\% menjadi 69,57\%. jadi terjadi peningkatan sebesar $52,18 \%$, dengan rata-rata 76,83 .

\section{Hasil Pengamatan Siklus 2}

Berdasarkan pengamatan yang dilakukan pada siklus 2 juga terjadi peningkatan, baik terhadap aktivitas maupun Hasil Belajar peserta didik dengan gambaran sebagai berikut: (1) mendengarkan penjelasan guru $(86,95 \%)$, (2) mengerjakan tugas kelompok (81,16\%), (3) bertanya $(52,17 \%)$, (4) menjawab pertanyaan $(69,57 \%),(5)$ berpendapat $(47,83 \%)$, dan (6) membuat kesimpulan $(88,40 \%)$.

Berdasarkan data dapat diambil kesimpulan bahwa terdapat peningkatan aktivitas peserta didik pada siklus 2 dibandingkan dengan kondisi pada siklus 1 yaitu sebesar 15,94\%. Dapat digambarkan dengan grafik sebagai berikut:

Gambar 1. peningkatan aktivitas peserta didik pada siklus 2 dibandingkan dengan kondisi pada siklus 1

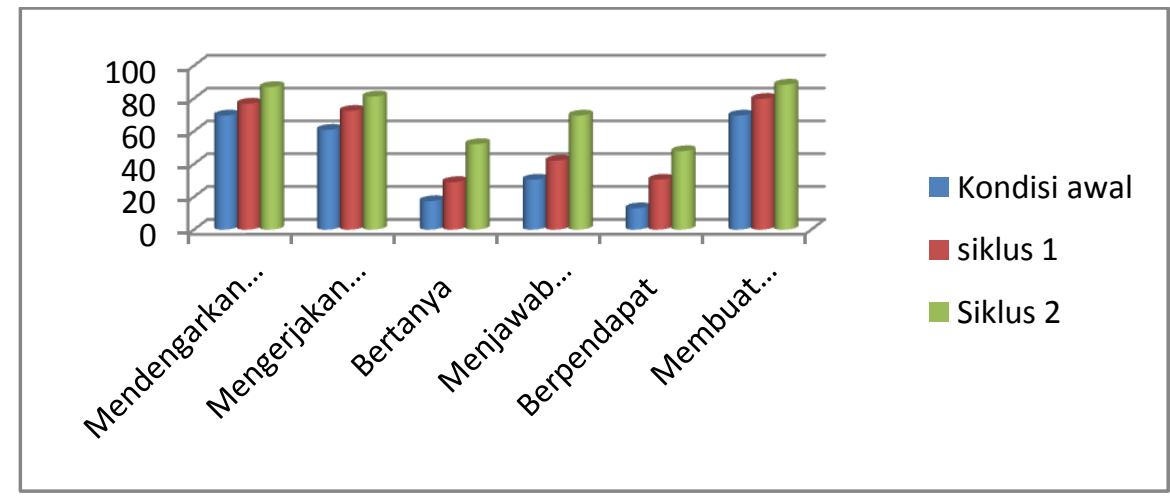


Hasil Belajar pada siklus 2 juga terdapat peningkatan yaitu dengan rata-rata 81,97 dan ketuntasan belajar sebesar 76,83\%. maka terjadi peningkatan hasil belajar peserta didik pada siklus 2 dibandingkan dengan hasil belajar pada siklus 1yaitu sebesar 8,69\%, .Rata-rata juga meningkat dari 76.83 menjadi 81,97 ( jadi meningkat 5,14\%). Dapat digambarkandengan grafik berikut:

Gambar 2. Hasil Belajar pada siklus 2

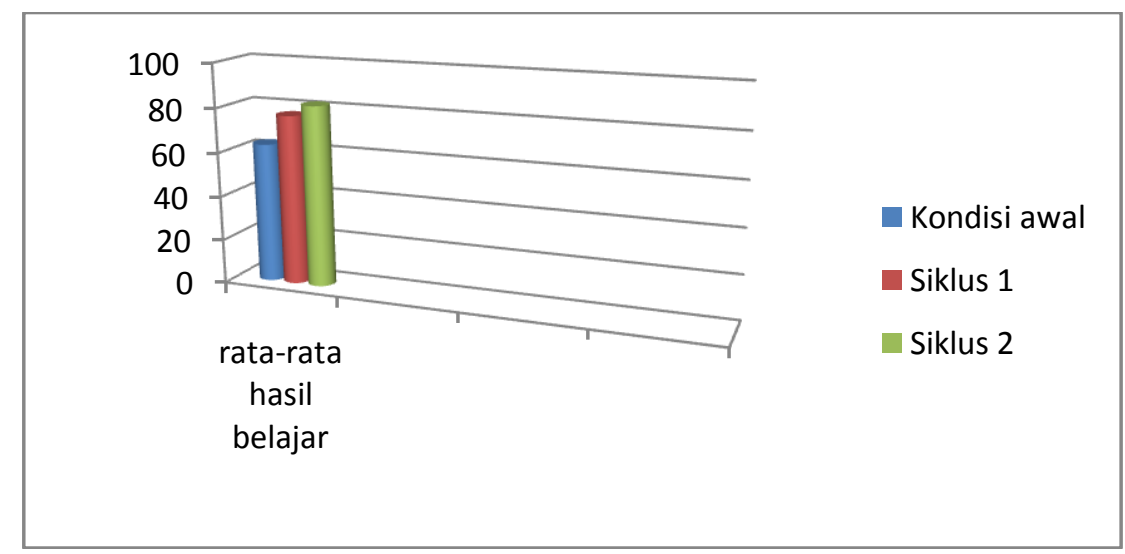

Rata-rata nilai tes proses Siklus $\mathrm{I}=76,83 \%$

Rat-rata nilai tes proses Siklus II $=81,97 \%$

Dari observasi yang dilakukan terjadi peningkatan hasil belajar peserta didik dari siklus 1 ke siklus 2 sebesar 5,14 \%, persentase rata-rata secara umum 79,40\%, berarti sudah melewati nilai KKM, maka model Student Teams Achievment Divisions (STAD) dapat diterapkan dalam pembelajaran IPS.

\section{SIMPULAN DAN SARAN Simpulan}

Berdasarkan data hasil penelitian yang telah dibahas pada Bab IV di atas dapat disimpulkan bahwa pelaksanaan pembelajaran dengan menggunakan model pembelajaran kooperatif tipe Student Teams Achievement Division (STAD) dapat meningkatkan aktivitas peserta didik dalam pembelajaran IPS. Hal ini terlihat dari meningkatnya aktivitas peserta didik dalam mendengarkan penjelasan guru, mengerjakan tugas kelompok, bertanya, menjawab pertanyaan, berpendapat saat menyimpylkan materi dan membuat catatan penting/kesimpulan. Pada kondisi awal siswa yang aktif sekitar 43,48 \%, pada siklus 1 siswa yang aktif dalam pembelajaran adalah 55,07 \% dengan kriteria rendah.

Pada siklus 2 aktivitas peserta didik mengalami peningkatan dengan persentase rata-rata 71,01\% dengan kriteria sedang. Sehingga dapat meningkatkan hasil belajar peserta didik dalam mata pelajaran IPS, dimana pada kondisi awal jumlah peserta didik yang tuntas adalah 63,13\%, dengan kategori rendah. Pada siklus 1 meningkat menjadi 76,83\% dengan kategori sedang dan siklus 2 menjadi 81,97\% dengan kategori tinggi. Perolehan angka ini sudah melebihi dari target indikator keberhasilan yang ditetapkan dalam proses pembelajaran.

\section{Saran}

Berdasarkan dapat penulis sampaikan sehubungan dengan hasil penelitian adalah: (1) peserta didik agar dapat terlibat aktif dalam pembelajaran sehingga dapat menguasai materi dengan baik, dan hasil belajarpun juga akan meningkat, (2) model pembelajaran Student Teams Achievement Divisions (STAD) juga dapat diterapkan oleh guru lain dengan mata pelajaran yang berbeda.

\section{DAFTAR RUJUKAN}

A.M, Sardiman. (2006). Interaksi dan Motivasi Belajar Mengajar. Jakarta: PT. Raja Grafindo Persada. Alex Maryunis. (1999). Pengantar Action Reseach Bidang Pendidikan: UNP Padang.

Arikunto, Suharsimi. (20030. Dasar-Dasar Evaluasi Pendidikan. Jakarta: Bumi Akasara.

Arikunto, Suharsimi. (2010). Prosedur Penelitian. Jakarta: Rieneka Cipta. 
Depdiknas, Dirjen Dikdasmen (2005). Materi Terintegrasi. Jakarta: Direktorat Pendidikan Lanjutan Pertama.

Depdiknas, Dirjen Dikdasmen. (2003). Pendekatan Kontekstual (Contextual Teaching and Learning-CT ). Jakarta: Direktorat Pendidikan Menengah Umum

Gustus, T. (2012). Keefektifan Penggunaan Model Pembelajaran Kooperatif Tipe Team Assisted Individualization (TAI) dalam Meningkatkan Minat Belajar Siswa dalam Pembelajaran PKM Kelas XI Mesin di SMK PIRI Sleman (Doctoral dissertation, UNY).

Johnson, D. W., \& Johnson, R. T. (1994). Learning together and alone. Cooperative, competitive, and individualistic learning. Allyn and Bacon, 160 Gould Street, Needham Heights, MA 02194..

Mulyasa.E. (2006). Kurikulum Bebasis Kompetensi. Bandung: PT. remaja Rosdakarya.

PPM SLTP. (1998). Petunjuk Praktis Pelaksanaan Action Research: Jakarta.

Prihati, Eka. (2008). Guru Sebagai Fasilitator. Bandung: Karsa Mandiri Persada

Purwanti, S. (2013). Peran Kepemimpinan Kepala Sekolah dalam Meningkatkan Disiplin Kerja Guru dan Pegawai di SMA Bakti Sejahtera Kecamatan Kongbeng Kabupaten Kutai Timur. eJournal Administrasi Negara, 1, 210-224.

Rahyubi, Heri. (2012). Teori-Teori Belajar dan aplikasi Pembelajaran Motorik Deskripsi dan Tinjauan Kritis. Bandung: Nusamedia.

Saadi, Ma'mur dkk. (2007). Strategi Pembelajaran Bahasa Indonesia. Jakarta: Universitas terbuka.

Sharan, S. E. (1994). Handbook of cooperative learning methods. Greenwood Press/Greenwood Publishing Group.

Slameto. (2010). Belajar dan Faktor yang Mempengaruhi. Jakarta: Raja Grasindo Persada.

Suhardan, D. (2007). Efektivitas Pengawasan Profesional dalam Meningkatkan Mutu Pembelajaran pada Era Otonomi Daerah. Educationist, 1(1), pp-57.

Syamsuri, I. (2010). Peningkatan Kompetensi Guru untuk Meningkatkan Minat Siswa pada Bidang MIPA. Makalah disampaikan dalam Lokakarya MIPAnet. 